\title{
CLINICAL FEATURES OF ADJUSTMENT DISORDER IN INTERNALLY DISPLACED WOMEN
}

DOI: 10.36740/WLek202006114

\author{
Larysa 0. Herasymenko, Rustam I. Isakov, Alina V. Halchenko, Pavlo V. Kydon \\ UKRAINIAN MEDICAL STOMATOLOGICAL ACADEMY, POLTAVA, UKRAINE
}

\begin{abstract}
The aim: To study the clinical features of internally displaced women with adjustment disorders.

Materials and methods: Clinical features of internally displaced women with adjustment disorders are investigated. Comprehensive clinical psychopathological and psychodiagnostic assessment of 58 women have been conducted, their medical history data have been analyzed.

Results: According to the analysis of the questionnaire severity of psychopathological symptoms prevalence of phobic anxiety, somatization with the presence of distress were observed in internally displaced women. In the clinical presentation of psychopathological disorders, the following symptoms of anxiety-depressive syndrome complex prevailed: mental fatigue $93.1 \pm 3.9 \%$; decrease in working capacity in $89.7 \pm 4.2 \%$ of women; decrease in $\operatorname{mood} 79.3 \pm 6.9 \%$; anxiety $75.7 \pm 3.8 \%$; decrease in libido in $65.7 \pm$ $4.9 \%$; physical fatigue $-51.7 \pm 4.4 \%$ of the examined.

Conclusions: Analysis of clinical and psychopathological symptoms of women with adjustment disorder indicates the dominance in the structure of symptoms of anxiety and depressive symptoms in mixed and isolated forms. According to the analysis of the questionnaire of severity of psychopathological symptoms, in internally displaced women, the prevalence of phobic anxiety, somatization with the presence of distress was observed.
\end{abstract}

KEY WORDS: adjustment disorder, psychosocial maladjustment, internally displaced persons

Wiad Lek. 2020;73(6):1154-1157

\section{INTRODUCTION}

The problem of various states of psychosocial maladjustment has been addressed in psychiatry for quite some time. In particular, attempts were made to describe them in the form of the following categories: nostalgia, psycho-emotional stress syndrome, premorbid forms of emotional stress, mental maladjustment, psychosocial maladjustment, prenosological states, maladjustment, or non-pathological neurotic manifestations. This list can be continued $[1,2,3]$.

In this context, the concept of the mental adaptation barrier is extremely impoartant and is an individual functional-dynamic formation that prevents overstrain of the mechanisms of mental maladjustment, which can result in the formation of a state of mental maladjustment and mental disorders, in particular neuroses.

The barrier of mental maladjustment is dynamic, and in the state of mental stress it approaches its individual critical value. At the same time, a person uses all his reserve capabilities and, in the case of a harmonious psychological attitude to a stressful situation, he sometimes becomes able to perform particularly complex activities without experiencing anxiety, fear and confusion, which impede the most adaptive behavior.

But the prolonged and especially sharp stress of the adaptation barrier functional activity leads to its overstrain, which manifests itself as a state of maladjustment [4]. If the pressure on the mechanisms of mental adaptation increases, and the reserve capacity is exhausted, then there is a "barrier tear" and the formation of borderline mental pathology [5].

Schematically, the process of maladjustment occurs according to the principle of a "vicious circle", where the releasing mechanism, as a rule, is a sharp change in living conditions, habitual environment, and the presence of a stable traumatic situation. And further, maladjustment exacerbates the existing mental and somatic disorders, leading to even greater maladjustment and subsequent deviations in functioning [6]. Numerous neurotic and psychosomatic symptoms accompanying psychosocial maladjustment are described in sufficient detail in the literature.

This problem has recently become particularly relevant in Ukraine, which in the context of a hybrid war faced a sharp increase in social tension caused by the fighting in the antiterroristic operation zone and a large number of migrated persons [7]. There are significant gender differences in crisis situations; in particular, women are the most vulnerable in a significant part of stressful situations $[8,9]$.

\section{THE AIM}

Considering this, the aim of the research is to study the clinical features of migrated women with adjustment disorders. 


\section{MATERIALS AND METHODS}

The study involved 58 women with diagnosed adjustment disorders (F43.2), who sought advice from the Cathedra of Psychiatry, Narcology and Medical Psychology of the "Ukrainian Medical Stomatological Academy". They all agreed to participate in the study.

They were given a comprehensive clinical, psychopathological and psychodiagnostic examination, and their anamnestic data was analyzed.

The scale of adaptation / maladjustment, or questionnaire for the severity of psychopathological symptoms (Simptom Check List-90-Revised-SCL-90-R), adapted by N. V. Tarabrina in co-authorship., 2001 - was used to assess the psychopathological status of women with adaptation disorders. This technique makes it possible to assess the presence and severity of a spectrum of psychopathological manifestations and individual symptoms in a patient.

\section{RESULTS AND DISCUSSION}

According to the obtained results, anamnestic among the comorbid pathologies the most common in the examined women were depression, anxiety-depressive reactions, diseases of the cardiovascular system (hypertension, atherosclerosis), and acute reactions to stress.

20 (34.5\%) women had suicidal statements in their past histories, and 2 (3.4\%) had incomplete suicidal attempts. At the time of the survey, all women did not have pronounced suicidal tendencies.

Hereditary factors analysis showed that the predispositional factors for the development of the corresponding neurotic pathology and psychosocial maladjustment in the women we examined were mainly hereditary factors (mental pathology in parents), dystontogenetic factors (pregnancy pathology), as well as manifestations of neurotic behavior in childhood.

The most important and most common factors of psychotrauma were the frustration of health needs, love, and happy family life. Maladjustment developed as a result of the discrepancy between expectations and the actual situation in family relations, the inability to remain in the current state of relations and the inability to find effective ways to resolve conflicts. In some patients maladjustment of family relations reached the degree of aversion, which covered both psychological and sexual spheres with the involvement of both conscious and unconscious mechanisms.

In the clinical presentation of psychopathological disorders, the following symptoms of anxiety-depressive syndrome complex prevailed: mental fatigue $93.1 \pm 3.9 \%$; decrease in working capacity in $89.7 \pm 4.2 \%$ of women; decrease in mood $79.3 \pm 6.9 \%$; anxiety $75.7 \pm 3.8 \%$; decrease in libido in $65.7 \pm$ $4.9 \%$; physical fatigue $-51.7 \pm 4.4 \%$ of the examined.

Clinical and psychopathological presentations detected in women, who suffer from adaptation disorders, are systematized in Table I.

According to the given table, such manifestations as memory disorders, lethargy, obsessions, mannerisms, dysuria were relatively atypical for the patients examined.
Table I. Clinical and psychopathological presentations in women suffering adaptation disorders

\begin{tabular}{|c|c|}
\hline Clinical sign & $(n=58) \% \pm m \%$ \\
\hline 1. Physical fatigability & $51,7 \pm 4,4$ \\
\hline 2. Mental fatigability & $93,1 \pm 3,9$ \\
\hline 3. Decreased working capacity & $89,7 \pm 4,2$ \\
\hline 4. Irritability & $29,3 \pm 4,9$ \\
\hline 5. Tearfulness & $36,5 \pm 3,7$ \\
\hline 6. Insomnia & $34,5 \pm 4,0$ \\
\hline 7. Memory disorders & $12,1 \pm 2,1$ \\
\hline 8. Attention disorder & $24,1 \pm 4,1$ \\
\hline 9. Decrease in mood & $79,3 \pm 6,9$ \\
\hline 10. Low self-esteem & $41,4 \pm 3,0$ \\
\hline 11. Lethargy & $8,6 \pm 1,9$ \\
\hline 12. Emotional lability & $46,5 \pm 3,7$ \\
\hline 13. Anxiety & $75,7 \pm 3,8$ \\
\hline 14. Obsessions & $10,3 \pm 1,4$ \\
\hline 15. Meteosensitivity & $15,5 \pm 2,7$ \\
\hline 16. Aggravation & $12,1 \pm 3,0$ \\
\hline 17. Hypochondria & $47,2 \pm 4,1$ \\
\hline 18. Paresthesias & $20,6 \pm 3,9$ \\
\hline 19. Ideational lethargy & $10,3 \pm 2,9$ \\
\hline 20. Headache & $42,5 \pm 4,2$ \\
\hline 21. Dizziness & $29,3 \pm 2,6$ \\
\hline 22. Cardialgia & $17,2 \pm 3,7$ \\
\hline 23. Blood pressure fluctuation & $43,1 \pm 4,1$ \\
\hline - hypertension & $18,9 \pm 3,2$ \\
\hline - hypotension & $6,9 \pm 3,3$ \\
\hline - lability & $20,7 \pm 3,9$ \\
\hline 24. Suffocation & $12,1 \pm 3,9$ \\
\hline 25. Nausea, vomiting & $22,4 \pm 3,1$ \\
\hline 26. Dysorexia & $33,8 \pm 1,2$ \\
\hline 27. Indigestion & $31,0 \pm 3,9$ \\
\hline 28. Dysuria & $6,9 \pm 1,8$ \\
\hline 29. Hyperhydrosis & $41,4 \pm 2,8$ \\
\hline 30. Vegetovascular paroxysms & $45,5 \pm 5,5$ \\
\hline 31. Decreased libido & $65,7 \pm 4,9$ \\
\hline 32. Dysmenorrhea & $18,9 \pm 2,4$ \\
\hline
\end{tabular}

Table II. Psychopathological syndromes in women with adjustment disorders

\begin{tabular}{cc}
\hline Syndromes & (n=58) $\% \pm \mathbf{m} \%$ \\
\hline 1. Anxiety-depressive & $53,4 \pm 4,9$ \\
\hline 2. Asteno-depressive & $18,9 \pm 3,7$ \\
\hline 3. Anxious & $20,6 \pm 2,9$ \\
\hline 4. Depressive & $25,8 \pm 4,1$ \\
\hline 5. Astheno-agripnic & $12,0 \pm 3,5$ \\
\hline
\end{tabular}


The most significant and common clinical signs for women with adaptation disorders were: mental fatigue, decreased working capacity, tearfulness, insomnia, reduced self-esteem, paresthesias, headaches, dizziness, blood pressure fluctuation, nausea and vomiting, dysorexia, dyspepsia, decreased libido, hyperhidrosis, vegetovascular paroxysms.

More detailed clinical and psychopathological analysis of the structure of clinical symptoms in patients with adaptation disorders showed that emotional disorders in patients in this group were characterized by a predominance of horror (53.4\%), fears (44.8\%), dissatisfaction with themselves (32.7\%). Anancastic (56.8\%) and asthenic (36.2\%) components with pronounced motor restlessness (39.6\%) were observed in the behavior.

Thinking disorders were manifested in the form of hypochondriacal thoughts (55.2\%) and exhaustion of mental activity (53.4\%). Somato-vegetative disorders were recorded as sexual dysfunctions (67.2\%) and headache (46.5\%).

Subjective state of mild depression of situational genesis was diagnosed in $36.2 \%$ of the examined women, and in $24.1 \%$ a moderate depressive episode was diagnosed.

In general, the clinical picture of adaptation disorders in the women examined was characterized by the predominance of anxiety-depressive symptoms with diverse manifestations of somatization.

The revealed patterns of clinical psychopathological features in women with signs of psychosocial maladjustment were confirmed by syndromic analysis. The results of the syndromic analysis of clinical manifestations are summarized in table II.

Analysis of the data obtained indicates that in women with adaptation disorders, the syndromic structure of the clinical picture is characterized by the predominance of mixed anxiety-depressive and pure anxiety and depressive clinical variants of psychopathological syndromes.

The results of the clinical examination were confirmed by the results obtained using the questionnaire on the severity of psychopathological symptoms (Simptom Check List-90Revised-SCL-90-R). Phobic anxiety (62.1\%), somatization (39.6\%) with distress (77.5\%) prevailed in the structure of anxiety disorders.

\section{CONCLUSIONS}

In general, an analysis of the clinical and psychopathological symptoms of women with adaptation disorders indicates that anxiety and depressive manifestations dominate in the structure of symptoms in mixed and isolated variants.

According to the analysis of the questionnaire of severity of psychopathological symptoms, in internally displaced women, the prevalence of phobic anxiety, somatization with the presence of distress was observed.

The obtained data can be used to build an effective system of psychotherapeutic correction of the manifestations of psychosocial maladjustment in migrated women and rehabilitation work with them.

\section{REFERENCES}

1. Goldberger L. Handbook of stress. Theoretical and clinical aspects. N.Y.: The Free Press; 2012. 804p.

2. Breslau N., Kessler R., Howard D. Et al. Trauma and posttraumatic stress disorder in the community. Arch. Gen. Psychiatry. 1998 Jul;55(7):626-32.

3. Herasymenko L.A. Nova metodyka diahnostyky psykhosotsial'noyi dezadaptatsiyi [A new method of diagnosis of psychosocial maladjusment]. Likars'ka sprava. 2018;1:2: 82-88 (Ua).

4. De Jong J.T., Komproe I.H., Van Ommeren M. Mental disorders in postconflict settings. Lancet. 2003; 361(9375); 2128- 2130.

5. Andreyeva G.M. Sotsial' naya psychologiya [Social Psychology]. Moscow, Moscow State University; 1980.280 p. (Ru).

6. Soeteman D.I. The economic burden of personality disorders in mental health care. The Journal of Clinical Psychiatry. 2008; 69: 259.

7. Herasymenko L.0., Isakov R.I. Maskovani depresiï v zagal'no-somatichnii praktitsi [Masked depression in general somatic practice].Aktual'ni problemy suchasnoyi medytsyny: Visn. Ukr. med. stomat. akad. 2013;13: 80-82. (Ua).

8. Israelashvili M. Should adjustment disorder be conceptualized as transitional disorder? In pursuit of adjustment disorders definition. Journal of Mental Health. 2012; 21(6): 579-88.

9. Herasymenko L.O. Diahnostyka psykhosotsial'noyi dezadaptatsiyi u zhinok z depresyvnymy rozladamy sotsiumi [Diagnosis of psychosocial maladaptation in women with depressive disorders]. World of Medicine and Biology. 2019;1 (67): 34-38. (Ua).

10. Maruta N.V., Yavdak I.O., Kalens'ka G.M., Al'ohina S.L. Kontseptsiya formuvannya nevrotichnih depresii u suchasnomu sotsiumi [The concept of formation of neurotic depression in modern society]. Arhiv psihiatriyi. 2003; 9(1): 17-20. (Ua).

11. Rahman L.V., Markova M.V., Kozhina G.M. Rol' stresovih faktoriv v sindromogenezi terapevtichno rezistentnih depresii [Role of stress factors in syndromogenesis of therapeutically resistant depression]. Ukrayins'kii visnik psihonevrologiyi. 2015; 23(3):163-164. (Ua).

12. Breslau N., Kessler R., Howard D. Et al. Trauma and posttraumatic stress disorder in the community. Archives of General Psychiatry. 1998; 55: 626-632.

13. Skrypnikov A.M., Herasymenko L.A., Isakov R.I. Psykhosotsial'na dezadaptatsiya pri posttravmatychnomu stresovomu rozladi u zhinok [Psychosocial malajustment in post-traumatic stress disorder in women]. Poltava: TOV «ASMl»; 2016. 168p.

14. Wittchen H.U., Jacobi F. Size and burden of mental disorders in Europe: a critical review and appraisal of 27 studies. Eur. Neuropsychopharmacol. 2005; 15 (4): 357-76.

15. Herasymenko L.A. Psychosocial aspects of adjustment disorders in women. Psychiatriya, psychotherapiya and clinical psychologiya. 2018; 1: 40-45. (Ua).

16. Kozhina G.M., Markova M.V., Mihailov V.B., Fel'dman DA. Klinichni osoblivosti nevrotichnih rozladiv u vnutrishn'o peremischenih osib [Clinical features of neurotic disorders in internally displaced persons]. Ukrayins'kii visnik psihonevrologiyi. 2015; 3(84): 129-130. (Ua).

17. Halchenko A.V. Suchasni vidminnosti psykhosotsial'noyi dezadaptatsiyi u vnutrishn'o peremishchenykh osib za nayavnosti nevrotychnoyi patolohiyi [Modern differences of psychosocial disadapation in internally moved persons with neurotic pathology]. Aktual'ni problemy suchasnoyi medytsyny: Visn. Ukr. med. stomat. akad. 2019; 1(65): $7-11$ (Ua).

18. Al-Baldawi R. Migration-related stress and psychosomatic consequences. International Congress Series. 2002 Sept. 1241: 271-78.19. Shieds J. (1973) Handbook of abnormal psychology, London: Pitman medical publishing. 
20. MarutaN.,Pan'koT.,FedchenkoV., Kutikov0. Rol'psykhotravmatyzatsiynykh faktoriv u formuvanni tryvozhno-fobichnykh rozladiv [The role of psychotraumatization factors in formation of anxious-phobic disorders]. 2012; 4: 25-28. (Ua).

The article is a fragment of the research "Psychosocial disadaptation in internally displaced persons (clinico-psychopathological, pathopsychological features and rehabilitation)» (State registration number 0119U102861).

ORCID and contributorship:

Larysa O. Herasymenko - 0000-0001-9002-3641 ${ }^{A, B, D, F}$

Rustam I. Isakov - 0000-0001-9127-2930 ${ }^{A, B, E}$

Alina V. Halchenko - 0000-0002-2379-7767 B,C,D

Pavlo V. Kydon - 0000-0001-8711-8228 C,E

\section{Conflict of interest:}

The Authors declare no conflict of interest.

\section{CORRESPONDING AUTHOR}

Alina V. Halchenko

Ukrainian Medical Stomatological Academy

8 Bayana St., 36002, Poltava, Ukraine

tel: +380999597801

e-mail:dr.galchenko@gmail.com

Received: 23.02 .2020

Accepted: 07.05 .2020 